\title{
Environmental Disclosure Quality Impact on Profitability Performance
}

\author{
Auliya Zulfatillah* \\ Faculty of Economics and Business, Airlangga University, Jl. Airlangga, No.4, Surabaya, Indonesia \\ *Corresponding Author: Auliya Zulfatillah, Faculty of Economics and Business, Airlangga University, \\ Jl. Airlangga, No.4, Surabaya, Indonesia
}

\begin{abstract}
Purpose: The purpose of this study is to investigate the impact of environmental disclosure quality impact on profitability performance to 115 manufacturing companies listed on Indonesia Stock Exchange (IDX) in 2017.

Design/Methodology/Approach: This study is quantitative researh because it uses statistical methods to resolve the problem. Data Analyzed using multiple linear regression model that allows to examine the direct effect of environmental discosure quality impact on profitability performance. The environmental disclosure classified into two categories, hard disclosure type and soft disclosure type.
\end{abstract}

Results: The findings of this study indicate that environmental disclosure quality impact positively on profitability performance through hard disclosure type, while soft environmental disclosure type does not affect corporate profitability performance.

Authenticity/Value:This study uses stakeholder theory as the basis to explain how to minimize gap between managers who run companies and stakeholders who have high expectation toward corporates performance.

Keywords: environmental disclosure, profitabiliy

\section{INTRODUCTION}

The global economic has been experiencing stumbling phases several years ago when the financial crisis hit various investment institutions in the USA. Investors unrealized about bubble economics phenomenon and misjudged it as economic strenght (Goodfrey, 2010). One of the causes of the financial crisis is the large numbers of companies that apply the concept of profit maximization that violates the profit maximization principle itself, including economic cost, accounting cost, and opportunity cost. (Suartana, 2009). The impacts of violations of these principles are the abandonment of environmental management, low environmental performance, and low corporates' intention to conserve the environment(Goodfrey, 2010).

Indonesia is also experiencing problems in environmental pollution as the same case in some other countries. This problem may certainly to be resolved if corporates managers are committed and willing to take responsibility for environmental conservation (William, 2012), in addition environmental pollutions are largely the result of corporate operation in conducting business (Epstein, 2008).

Corporate disclosure is an important tool to delivercorporates performances in economic aspect, environmental aspect, and social aspect (Goffrey, 2010). Corporates disclosures includeall of informations that consist of corporatesactivities about financial or non-financial performance that relate to how companiesmanage theirphysical environment and their social environment (Clarkson, 2008). Good corporate disclosure should provide information about the extent to which a company can contribute to the quality of life of the community and its environment (Dhaliwal, 2011). Environmental disclosure is stated in corporates annual report as one of voluntary disclosure (Sari, 2012). The presence or absence of environmental disclosure comes from corporate initiatives, because there is no regulation that requires companies todisclose their environmental activities.

The research of Pfleiger et al (2005) in Suhardjanto (2009) concludes that corporatesenvironmental conservation actwill provide benefits.Investors have more attract to responsible companies which 
involve environmental management as part of their corporate value (Karim et al, 2014). Environmental act will also increase corporate branding and corporate value from investors view, which ultimately affects the corporatesprofitability performance (Dhaliwal, 2011). One of important way in order to involve environmental act as corporate value is to include CSR activities and environmental performance as one of the corporates competitive strategy (Clarkson, 2008). It shows public that corporates act as good corporate citizens will have positive impact not only for environment but also for corporate business sustainability.

\section{THEORETICAL GROUND}

\subsection{Stakeholder Theory}

Stakeholder theory explains how managements or companies meet and manage expectations of stakeholders. Any group or individual that can influence or be influenced by achievements and objectives of companies are called stakeholders, so that the existence of a company will be affected by the support of stakeholders. There are two categories of stakeholders, inside stakeholders and outside stakeholders (Andriani, 2017).

Stakeholders who have interests on corporate resources and are within the organizational structure of the company are called inside stakeholders (Deegan, 2000). Included in the category of inside stakeholders are shareholders, employees, and top managements (Soelistyoningrum, 2011). While outside stakeholders are any group consisting of parties outside the organizational structure of the company, but have interests on company because influenced by every decision and action of corporate strategies (Deegan, 2000). Included in the category of outside stakeholders are customers, investors, creditors, suppliers, government, community, citizens and environment (Soelistyoningrum, 2011).

Companies have responsibility for all of stakeholder'scategories, not limited to certain stakeholders (Chariri and Ghozali, 2007). This idea encourages corporate social responsibility, which initially just focus on shareholders in term of profit maximization, to becomeresponsibility for all stakeholders and communities widely (Deegan, 2000). Refers to arguments described by stakeholder theory, companies should not only conduct operations for their own purposes, but all oftheir business should be able to provide benefits for all stakeholders (Hari, 2011). Environmental disclosure as part of corporate social responsibility is a way that can satisfy all types of stakeholders.

\subsection{Environmental Accounting}

Environmental accounting is a term to classify type of budget allocationfor doing environmental conservation, it clasifies into two categories, these are environmental post and business practices (Octavia, 2012). Environmental accounting is integrating environmental costs to corporates accountingpractices (Geoff, 2005). According to the United States Environment Protection Agency (US EPA), environmental accounting is a function that describes environmental costs that should be considered by corporate stakeholders in identifying ways that can reduce or avoid costs at the same time through environmental improvement efforts (Jasch, 2002).

Environmental conservation activities will emphasize environmental costs as corporates expense.In definition, environmental accounting is a quantitative measurement framework for corporates environmental conservation activities. According to Lindrianasari (2007) in Suartana (2009), activities related to environmental conservation are:

1) Conservation for bad quality environment which affect the exsistence of living in condition of high air pollution, water pollution, soil pollution, noise, vibration, and bad smell.

2) Conservation for bad quality environment which impact global condition, such as global warming, ozone layer depletion, and sea contamination.

3) Conservation for natural resources. This conservation can be done by reducing the use of chemicals which contaminate and pollute environment, emphasing waste management, and uing recycled materials to produce eco friendly products.

According to Berry and Rondinelli (1998) in Suartana (2009), there are several factors encourage companies to take environmental management action. These factors include:

1) Regulatory demand. Corporates environmental responsibility have emerged over the past 30 years as communities step up pressure on governments to enact government regulation as widespread 
pollutions become higher. Environmental management monitoring systems are basis for environmental scoring, such as health and environmental security program. It is important for companies to earn some awards in environmental field, by striving to apply the principles of TQEM (Total Quality Environmental Management) effectively.

2) Cost factors. Consumers complaints against corporates products will bring consequences of high quality supervision costs as all activities involved in the production process need to be well prepared. This will directly affect the emergence of high costs, such as raw material sorting costs, production process supervision costs, and testing costs. Corporates strategy to reduce pollution consequences on various costs for several expenses, such as the provision of waste treatment, the use of clean technology engine, and the cost of hygiene prevention.

3) Stakeholder forces. A proactive approach to environmental management built on management principles, such as reducing waste and reducing production costs.

4) Competitive requirements. Global market growth and emergence of various trade agreements are very influential on the emergence of the standardization movement of environmental quality management. Both national and international competition have demanded corporates to obtain assurance environmental quality aspect.

5) External motivation. An external factors which encourage companies and organizations to proactively manage the environment. Proactive management system is a comprehensive environmental management system, consisting of at least environmental design, stewardship, and full-costing accounting.

a. Environmental design is a system to reduce reprocessing costs and products return quickly and economically. Corporates are often face wasteful costs in designing products, for example products cannot be reassembled, repaired and recycled.

b. Stewardship is practices to reduce risks which impact environment through problems solving in terms of designing, manufacturing, distributing, using or selling products. Some countries have established regulations which force companies to take responsible actions for reclaiming, recycling, and re-manufacturing their products.

c. Full-costing is concept of environmental cost disclosure that directly affects individuals, communities, and environment. It usually does not get much attentions from companies. Full-cost accounting seeks to identify and quantify the environmental cost performance of a product, a production process and a project by considering four different costs; direct costs, indirect costs, uncertain costs, and intangible costs.

Environmental costs are often defined narrowly and partially as costs incurred in the pursuit of environmental laws or regulations. This is because the accounting system tends to focus on clearly identified business costs while ignoring costs and benefits from alternative options, whereas accounting is so varies in accounting choices.

\subsection{Environmental Disclosure}

Top managements as inside stakeholders use annual report as the main media in providing financial and non-financial information to outside stakeholders. The level of information that can be obtained depends on the level of disclosure of the corporates financial statements. The amount of information disclosed depends not only on the expertise of the reader, but also depends on adequate standards. Three general concepts used in the annual report are adequate, fair and full disclosure (Hendrikson, 2001, in Suhardjanto, 2009).

There are two types of disclosure: mandatory disclosure which refers to regulations and laws, and voluntary disclosure which depend on corporate policies (Golob and Barlett, 2007). Companies will disclosevoluntary disclosure to meet stakeholder's expectation and improve corporates reputationalthough they should expend additional costs. Environmental disclosures role as media communication medium in decision-making, economic, social, and political. Environmental responsibility is also a response to fulfill information needs of various interest parties, such as workers, environmental activists, and public communities.

According to Karim et al (2013), there are several approaches used in measuring the quality of corporate disclosure reporting, for example is the measurement of quality environmental disclosure by 
independent parties through several studies, such as Deloitte Touche Tohmatsu (1999), Pacific Sustainability Index, from a combination of GRI standards, ISO 14031, and SA8000 Guidelines. However, from these standards, KPMG (2005) states that GRI standards are the most dominant.In this study the quality environmental disclosure is measured using an index developed by Clarkson (2008). This index was developed through the adoption of environmental indicators within the GRI standard with some modifications in several aspects based on expertise advice in various industries (Plumlee et al, 2010).

Including in the Clarkson Index (2008) there are two categories of environmental disclosure, hard disclosure type and soft disclosure type. Of the 95 indicators contained in the index, 79 indicators are included in the category of hard disclosure type. Hard disclosure items contain information on the corporate governance structure, thecorporatesenvironmental management system, the corporates credibility in disclosing environmental performance, disclosure of specific environmental indicators, environmental costs and environmental investments. Meanwhile, the remaining 16 indicators are included in the soft disclosure category. The items in the soft disclosure category contain information about the corporates mission vision and environmental strategy that will apply, corporates environmental disclosure profile, and corporates initiatives related to environmental activities (Clarkson, 2008).

Through the classification of environmental disclosure type, it can be assessed the extent to which the corporates' commitment to disclose environmental information and manage good environmental performance (Plumlee et al, 2010), whereas Indonesia still not apply regulation related to environmental performance reporting capacity.

\subsection{Profitability}

Profitability is the end result of a whole set of management policies and decisions. All policies and decisions decided by management have a high impact on corporates resources and budget allocation which stated in financial statement. A corporation established to generate profits, it is normal that profitability is a major concern of financial analysts and investors. If companies consistent in generate profits, then they will be able to survive in doing business. Shareholders invest their assets to obtain profitable return, which consists of dividends and capital gains, the higher the profitability, the greater the expected return of investors.

The relationship between profitability and disclosure is a reflection of social response in order to maintain the existence of corporates business. Thus, environmental disclosure decisions are believed to be management approach to reduce social pressure and respond to social needs (Hackston and Milne, 1996, in Suhardjanto, 2009). Another reason is that companies will disclose more information when they are able to generate greater profits, so that investors and creditors believe that companies are in a strong position and their operational are efficient.

In this study profitability performance proxied by ROE (Return on Equity). ROE is a reflection of profits to be gained by investors as the numbers of each their invested shares. ROE is an important ratios used in analytical techniques that are commonly used to measure the effectiveness of a corporates overall operations.

\subsection{Environmental Disclosure Quality and Profitability}

Environmental disclosure include asvoluntary disclosure category, but many companies choose to disclose this information as an initiative to provide reliable information. Several companies even decide to take certification in environmental field and choose to be audited by an independent institution. According to Plumlee et al (2010), companies' commitment in environmental aspect can be differed based on their way to conduct environmental disclosure type.

There have been several previous studies on corporate environmental disclosure and financial performance. Karim et al (2013) examined the relationship between CSR disclosure quality and firm value. The CSR disclosure index used was GRI G3.1, the results concluded that CSR quality disclosure and firm value are positively related. In 2012, Sari examined the effect of CSR disclosure on profitability and corporate image. The results showed that there was no significant influence between CSR disclosure quality and companies profitability.

The clear image of how corporates commitment to environment can be judged on how companies manage their environmental issues. Therefore, in this study empirical testing applied to prove how 
quality environmental disclosure impact on profitability performance based on type of environmental disclosure presented whether include as hard disclosure type or soft disclosure type. Test results in both categories will be analyzed to see which categories have a significant effect on corporates profitability performance.

When a company discloses the environment with details through the hard disclosure type, informations which will received by stakeholderswill be more detail, it should have a positive impact on corporates profitability performance. Fich (2005) in Dahlia and Siregar (2008) stated that corporate disclosure is one way to manage corporate relationships with stakeholders, such as improved financial performance, increased competitive advantage, profit maximization, and long-term company success. Thus, when a company discloses its environmental performance clearly and explicitly it is expected to provide concrete evidence that corporates business activities are not only oriented to financial aspect but also concerned with social and environmental issues (Clarkson, 2008), thereby increasing corporates values through investment increasing which impacts on higher profit (Sari, 2012). Based on these arguments, environmental disclosure as hard disclosure category is predicted to have a positive effect on firm value, as stated in the following research hypothesis:

\section{$H_{1}$ : Environmental hard disclosure type has a positive effect on corporates'profitability performance.}

The second categoryis environmental disclosure as soft disclosure type. Informations disclosed in this category is general. Typically, start-up companies to perform environmental disclosures will select this category in their reporting. Information contained in soft disclosure category such as, corporates longterm vision and shortterm mission regarding environmental issues, company environmental strategy, environmental disclosure profile described by the company, and kind of initiatives which will be afforded by companiesto disclose their environmental performance (Clarkson, 2008).

Soft environmental disclosure will be easier to understand because it contains information which does not specific but still provide clear overview about corporates general environmental performance (Plumlee et al, 2010). Based on these arguments, environmental disclosure as soft disclosure category is predicted to have a positive effect on firm value, as stated in the following research hypothesis

\section{$\mathrm{H}_{2}$ : Environmental soft disclosure tye has a positife effect on corporates' rofitability performance.}

\subsection{Research Model}

Based on the theoretical framework discussed earlier, a conceptual framework is arranged as shown in Figure 1.

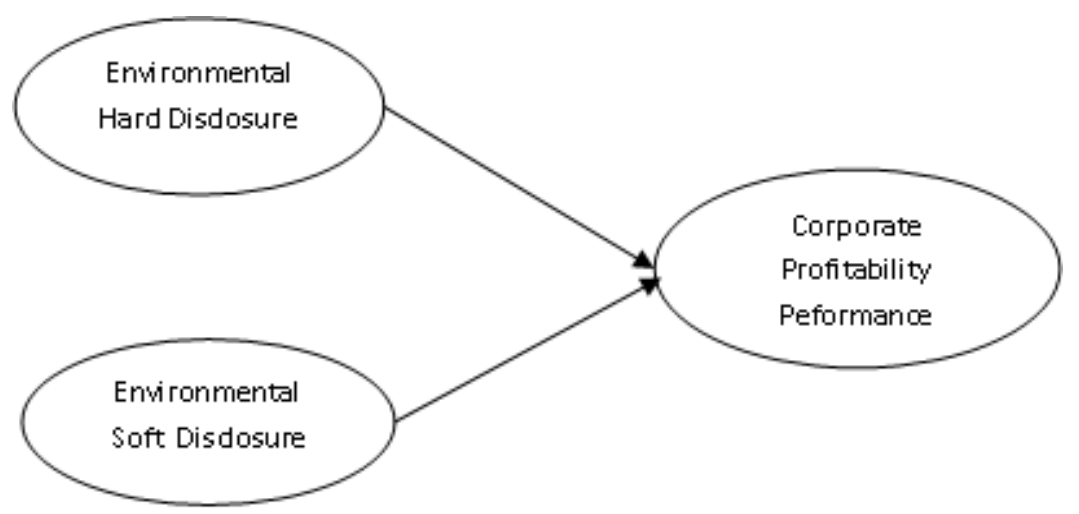

Figure1: Conceptual Framework of Research

\section{RESEARCH METHOD}

This research is quantitative research, all datas used are secondary data. Financial ratios data were obtained through corporates financial statement, while environmental disclosure data were obtained from annual reports of each companies downloaded from official website of Indonesia Stock Exchange (IDX).

The research objects are manufacturing companies listed in Indonesia Stock Exchange in 2017. This study used purposive sampling method with certain criterions and obtained 115 companies as research samples. Manufacturing companies were selected as research samples because their business operational give highest environmental impacts compared to others industries, in addition, this 
industry is subject to various environmental regulations in Indonesia, among others Government Regulation Number 74, 2001, management of hazardous and toxic materials, and Law No. 32, 2009, on environmental protection and management.

Return on Earning (ROE) is used in this study as proxy to represent corporates profitability performance. ROE measured by dividing Net Income to Total Equity.Independent variable in this study are environmental disclosure quality which divided into two categories, those are hard disclosure and soft disclosure. Environmental disclosure quality collected by using content analysis to corporates annual report and corporates sustainability report using an environmental assessment index adopted from Clarkson's (2008), which contains 96 indicators consisting of 75 hard disclosure items and 21 soft disclosure items.

Data analyzed by conducting empirical test using multiple linear regression method which arranged as shown in these formula:

Model 1:

$R O E i=\beta 0+\beta 1$ TYPE_HARD $i+\beta 2 S R i+\beta 3$ BVi $+\beta 4$ PROPER $i+\beta 5$ SIZE $i+e$

Model 2:

$R O E i=\beta 0+\beta 1$ TYPE_SOFT $i+\beta 2$ SR $i+\beta 3$ BVi $+\beta 4$ PROPER $i+\beta 5$ SIZE $i+e$

In which:

TYPE_HARD

: Type of environmental disclosure, measured by accumulating indicators in Hard Disclosure (HardD) category as stated inClarkson index.

TYPE_SOFT

: Type of environmental disclosure, measured by accumulating indicators in Soft Disclosure category (SoftD) as stated in Clarkson index.

$S R$

:Sustainability Report, a dummy variable, 1 for firms published Sustainability Report, 0 for firms which do not published Sustainability Report.

$B V$

: Book Value per Share

SIZE

: Size of firms, measured by computing the Logarithm of total assets.

PROPER

: Criteria conducted by The Ministry of Environment of the Republic of Indonesia to measure corporates'environmental activities

$e$

:Error term

\section{ANALYSIS AND DISCUSSION}

\subsection{Statistical Descriptive}

Table 1 as shown below explain how statistical descriptive of 115 firms as research samples tested. Environmental disclosures in this research are divided into two categories of hard disclosure and soft disclosure. For hard disclosure category the mean value is 0.376 while the soft disclosure category the mean value is 0.684 . Based on these means values in two categories, it indicates that in average firms have attend to disclose their environmental performance by using soft environmental disclosure type.It also reinforced by the maximum value of soft disclosure category that reaches $100 \%$, while for hard disclosure category the maximum value is only 0.81 . This is natural phenomena because high environmental disclosure need high extra costfor preparing detailed data and high time-consuming due to theircomplexity. Thus, as long as environmental disclosure still being part of voluntary disclosure, then the company will prefer environmental soft disclosure category.

Table1: Statistical Descriptive

\begin{tabular}{|l|l|l|l|l|}
\hline \multicolumn{1}{|c|}{ Variable } & \multicolumn{1}{c|}{ Mean } & \multicolumn{1}{c|}{ Std. Dev. } & \multicolumn{1}{c|}{ Min } & \multicolumn{1}{c|}{ Max } \\
\hline SoftD & 0.684 & 0.201 & 0.188 & 1 \\
\hline HardD & 0.376 & 0.189 & 0.087 & 0.810 \\
\hline ROE & 0.068 & 0.110 & -0.25 & 0.652 \\
\hline SR & 0.157 & 0.365 & 0 & 1 \\
\hline PROPER & 0.536 & 0.213 & 0.2 & 1 \\
\hline Size & 9.275 & 0.889 & 6.345 & 10.916 \\
\hline
\end{tabular}




\subsection{BLUE Test}

There are two classical assumption test or BLUE test conducted in this research, these are multicollinearity test and heterokedasticity test. This research does not use autocorrelation test, because the data is cross sectional, using only one year period of research.

The multicollinearity test results are presented in table 2.1 by calculating the mean value of VIF (Variance Inflation Factor). The multicollinearitytest for model 1 arranged in table 2.1 shows that value of mean VIF is 1.44 , while the mean value of VIF model 2 is 1.41 . If the mean value of VIF $<10$, it can be concluded that there is no multicollinearity problem in both research models.

Table2.1: Multicollinearity Test

\begin{tabular}{|c|c|c|c|c|}
\hline \multicolumn{2}{|c|}{ Model 1} & \multirow{2}{*}{ Variables } & \multicolumn{2}{|c|}{ Model 2} \\
\hline VIF & $1 / \mathrm{VIF}$ & & VIF & 1/VIF \\
\hline 1.81 & 0.553 & HardD & & \\
\hline & & SoftD & 1.69 & 0.591 \\
\hline 1.60 & 0.626 & PROPER & 1.56 & 0.640 \\
\hline 1.50 & 0.667 & Size & 1.53 & 0.653 \\
\hline 1.22 & 0.823 & SR & 1.17 & 0.855 \\
\hline 1.08 & 0.923 & BV & 1.10 & 0,911 \\
\hline 1.44 & & Mean VIF & 1.41 & \\
\hline
\end{tabular}

The heterokedasticity test is done by using Breusch-Pagan / Cool-Weisberg test.The result of Breusch-Pagan / Cool-Weisberg test for model 1 shows the value of Prob> chi2 of 0.00, as well as for model 2. The interpretation, if Prob value> chi2 shows value above 0.05 , the model is declared free of heterokedasticity. However, both models in this study are known to contain heterokedasticity problem so it is necessary to do certain treatment to overcome them. In this study, we use the "robust" command to resolve heterokedasticity problems. The "robust" command will automatically eliminate heterokedasticity through weighting on robust standard error. After applying "robust" the regression result obtained has been assuredly free from heterokedasticiy problem and can be interpreted correctly.

\subsection{Hypothesis Test}

Hypothesis test is conducted to determine the feasibility of the model, the level of significance of independent variables to the dependent variable, and to indicate the direction of the relationship that occurred. The test results presented in the hypothesis test include model significance test ( $\mathrm{F}$ test), model feasibility test ( $\mathrm{R}^{2}$ value), and partial significance test ( $\mathrm{t}$ test).

Table 3.1 presents the test results of model significance ( $\mathrm{F}$ test) on both models of this study. Model 1 and model 2 in this study show Prob value $>F=0.0002$. It could be interpreted thatif the value Prob> $\mathrm{F}$ less than 0.05 then the model used is considered significant. Thus, it can be concluded that the independent variables and control variables used in this study simultaneously have a significant effect on dependent variable.

Next is the determination of coefficient test, the purpose is to measure whether each model applied in the research is able to explain the influence of independent variables to dependent variable. The greater the value of the coefficient of determination, the greater the ability of independent variables in explaining the dependent variable. In this study based on table 3.1, it could be interpreted that the value of $\mathrm{R}^{2}$ model 1 is 0.6482 , that result indicate that the combination of independent variables in the model able to explain the dependent variable for $64.82 \%$. For model 2, it could be interpreted that the combination of independent variables in the model is able to explain the dependent variable for $64.57 \%$.

Table3.1: Significance Test \& Coefficient Test

\begin{tabular}{|l|l|l|}
\hline \multicolumn{1}{|c|}{ Measurements } & \multicolumn{1}{|c|}{ Model 1 } & \multicolumn{1}{c|}{ Model 2 } \\
\hline F & 5.32 & 5.37 \\
\hline Prob > F & 0.0002 & 0.0002 \\
\hline $\mathrm{R}^{2}$ & 0.6482 & 0.6457 \\
\hline Root MSE & 866.2 & 869.3 \\
\hline
\end{tabular}

Partial significance test ( $\mathrm{t}$ test) is examined to measure the influence of independent variables individually to the dependent variable. The coefficient value of the independent variable determines 
the direction of the relationship on the dependent variable whether positive or negative. Significant levels used are $90 \%(\alpha=10 \%), 95 \%(\alpha=5 \%)$, and $99 \%(\alpha=1 \%)$. Thus, if the Prob>t value of each independent variable is less than $0.1,0.05$, or 0.01 , then the independent variable has a significant influence on the dependent variable.

In model 1 it results that the value of Prob>t for variable hard disclosure type is 0.094 ; this value is less than 0.1 , so the hard disclosure variable significantly influence the ROE at level $10 \%$. While in model 2 the value of Prob>t for variable soft disclosure is 0.118 , the value is above the level of significance 0.1 , so it can be concluded that the soft disclosure variable has no effect on the ROE. Table 3.2 belows is arranged to explain clearly regarding the $t$ test results for all variables used in this study.

Table3.2: Partial Significance Test

\begin{tabular}{|c|c|c|c|c|}
\hline \multicolumn{2}{|c|}{ Model 1} & \multirow[t]{2}{*}{ Variables } & \multicolumn{2}{|c|}{ Model 2} \\
\hline Coeff & $\mathbf{P}>|\mathbf{t}|$ & & Coeff & $\mathbf{P}>|\mathbf{t}|$ \\
\hline 988.09 & 0.094 & HardD & & \\
\hline & & SoftD & 766.638 & 0.118 \\
\hline 871.036 & 0.032 & PROPER & 943.444 & 0.037 \\
\hline-733.057 & 0.014 & Size & -730.811 & 0.014 \\
\hline-197.109 & 0.362 & SR & -113.946 & 0.596 \\
\hline 0.097 & 0.002 & BV & 0.100 & 0.002 \\
\hline
\end{tabular}

\subsection{Discussion}

In this research, hard disclosure category is examined based on model 1 while soft disclosure category is examined based on model 2. Empirical test results through multiple linear regression show that hard disclosure variable has a significant positive effect on corporates profitability while soft disclosure variable has no effect to corporates profitability.Thus, it can be concluded that when the company took the initiative to create environmental disclosure in hard disclosure type, then the profit potential that will be obtained by the company will be greater than just doing some unclear environmental disclosure in the soft disclosure category.

Corporates stakeholders, especially investors and creditors as parties who play a major role in financing corporates business activities have greater interest in companies that could disclose information environment in detail, clear, and complex, because they assume that the information contained in the detailed reporting can describe the company's environmental performance in real (Plumlee et al, 2010). The corporates commitment to preserve environment can be reflected in their efforts to reveal their environmental activities.

There are enormous environmental costs that companies sacrifice to conserve the environment, if it is disclosed to the public, it can also be an incentive for companies to get a good image (Goffrey, 2010). In addition, when a company does indeed contribute to the environment, they will be motivated to disclose it to public widely to strengthen their position in the industry more than their competitors.

The results of this study are in line with someprevious researchs of Clarkson's (2008) and Plumlee et al (2010). These researchers concluded that environmental performance has positive effect on environmental disclosure. Clarkson (2008) also stated that when environmental disclosures applied in hard disclosure type, their informations will not be easily imitated by other companies, and it isdistinguished between companies that really care about environmental sustainability compare to companies who just follow trends only.

\section{CONCLUSIONS AND RECOMMENDATIONS}

This research was conducted to examine the effect of environmental dislosure quality impact on corporates profitability performance. Applied as sampling research are 115 manufacturing companies listed on the Indonesia Stock Exchange (IDX) in 2017. The quality of environmental disclosure was assessed using assessment indexes compiled by Clarkson (2008) with reference to GRI indicators. Profitability as a dependent variable is peroxided in the ratio of ROE. After empirical testing using multiple linear regression, the conclusion of this study is, environmental disclosure in the hard disclosure category has a positive effect on corporaes profitability performance, thus $\mathrm{H} 1$ is accepted. Meanwhile, based on empirical testing, environmental disclosure in the soft disclosure category has no effect on corporates profitability performance, thus $\mathrm{H} 2$ is rejected. 
There are several limitation in this study that might be a reference and consideration for further research. First, the research sample is limited to only manufacturing industry. It would be better if further research was conducted with broader and cross-industry sample coverage. Second, do not use only one point of view in assessing the quality of environmental disclosure. Furthermore, researchers can collaborate with fellow experiments to see how the corporatesenvironmental disclosure quality from the perspective of others expertise.

\section{REFERENCES}

[1] Agustina, S., 2013. Pengaruhprofitabilitasdanpengungkapan corporate social responsibility terhadapnilaiperusahaan. JurnalAkuntansi, 1(1).

[2] ANDRIANI, S., 2017. PengaruhKinerjaKeuanganTerhadapNilai Perusahaan DenganPengungkapan Corporate Social Responsibility SebagaiVariabelModerasi.

[3] Clarkson, P.M., Li, Y., Richardson, G.D. and Vasvari, F.P., 2008. Revisiting the relation between environmental performance and environmental disclosure: An empirical analysis. Accounting, organizations and society, 33(4), pp.303-327.

[4] Dahlia, Lely dan Silvia Veronica Siregar. 2008. "Pengaruh Corporate Social Responsibility TerhadapKinerja Perusahaan. StudiEmpirisPada Perusahaan yang Tercatat di Bursa Efek Indonesia PadaTahun 2005 dan 2006" SNA XI, Pontianak.

[5] Deegan, C., Blomquist,C., (2000). Stakeholder Infulence on Corporate Reporting: An Exploration of The Interaction Between The World Wide Fund For Nature and the Australian Minerals Industri. Working Paper.

[6] Dhaliwal, D., Zhen Li., Tsang Albert., George Yang. (2014). Corporate Social Responsibility Disclosure and The Cost of Equity Capital: The Role of Stakeholder Orientation and Financial Transparency. Journal of Accounting Public Policy.

[7] Geoff, L. (2005). Sustainability Accounting: A Brief History and Conceptual Framework. Accounting Forum.

[8] Geoffrey B., Laureen A. (2011). The Benefits and Cost of Corporate Social Responsibility. Elsevier.

[9] Jasch, Chiristine. (2002). The Use of Environmental Management Accounting for Identifiying Environmental Cost. Journal of Cleaner Production.

[10] Karim, Nina Karina., Mukhtaruddin.,Marwah, dkk. (2013). The Quality of Voluntary Corporate Social Responsibility Disclosure Effect on The Firm Value of Service Company Listed In The Indonesian Stock Exchange. Proquest.

[11] Octavia, Itsna. (2012). PengaruhPengungkapanLingkunganTerhadapNilaiPerusahaadenganProfitabilitas Sebagai VariabelModerasi. Skripsi S1. Universitas Indonesia.

[12] Perdana Sari, Harinda. 2012. AnalisisHubungan Corporate Social Responsibility Disclosure DenganProfitabilitas Perusahaan dan Image Perusahaan. Skripsi S1. Universitas Indonesia.

[13] Plumlee, M., Brown, D. and Marshall, S., 2010. The impact of voluntary environmental disclosure quality on firm value.

[14] SoelistyoningrumdanPrastiwi, JeniaNur. (2011) PengaruhPengungkapan Sustainability report TerhadapKinerjaKeuangan Perusahaan: StudiEmpirisPada Perusahaan Yang TerdaftarDalam Bursa Efek Indonesia. JurnalAkuntansiUniversitasDiponegoro Semarang.

[15] Suartana, I.W., 2009. Akuntansilingkungandan triple bottom line accounting: Paradigmabaruakuntansibernilaitambah. Bumi Lestari, 10(1).

[16] Suhardjanto, D. and Miranti, L., 2009. Indonesian Environmental Reporting Index danKarakteristik Perusahaan. JurnalAkuntansidan Auditing Indonesia, 13(1).

[17] William. (2012). PengaruhPengungkapan Corporate Social Responsibility BerdasarkanPedoman Global Reporting Initiative TehadapNilai Perusahaan. Tesis S2. Universitas Indonesia.

Citation: Auliya Zulfatillah. "Environmental Disclosure Quality Impact on Profitability Performance" International Journal of Managerial Studies and Research (IJMSR), vol 7, no. 10, 2019, pp. 33-41. doi: http://dx. doi.org/10.20431/2349-0349.0710005.

Copyright: ( $) 2019$ Authors. This is an open-access article distributed under the terms of the Creative Commons Attribution License, which permits unrestricted use, distribution, and reproduction in any medium, provided the original author and source are credited. 